\title{
EIF4B Gene
}

National Cancer Institute

\section{Source}

National Cancer Institute. ElF4B Gene. NCI Thesaurus. Code C121143.

This gene plays a role in the binding of mRNA to ribosomes. 